\title{
HUBUNGAN PERSEPSI ANCAMAN BENCANA KEBAKARAN DENGAN PENGAMBILAN KEPUTUSAN EVAKUASI DI KELURAHAN X KOTA PALEMBANG
}

\author{
Nyimas Anindya Medina Azzura ${ }^{1}$, Novrikasari ${ }^{2}$, Muhammad Hatta Dahlan ${ }^{3}$ \\ Program Studi Magister Ilmu Kesehatan Masyarakat, Fakultas Kesehatan Masyarakat, Universitas \\ Sriwijaya, Indonesia ${ }^{1,2}$ \\ Program Studi Teknik Kimia, Fakultas Teknik, Universitas Sriwijaya, Indonesia ${ }^{3}$ \\ anindyanyimas@gmail.com¹ ${ }^{1}$ novrikasari@fkm.unsri.ac.id ${ }^{2}$
}

\begin{abstract}
The fire disaster that occurred in $X$ sub-district was one of the biggest disasters during the period of 2018-2020 in Palembang since the related sub-district is a densely populated area that could take a part to contribute to the next disaster emergency responses in the area. The evacuation is acknowledged as the part of Emergency Response Plan which aims to reduce the impact of a disaster. The decision-making on the evacuation plan is influenced by several factors, one of which is people's perception towards the threat of fire disaster. Therefore, this study aims to identify the relation between the perception of the threat of fire disasters towards the decision-making for the evacuation plan. The methodology used in this study was Quantitative with a Cross-Sectional design. The sampling technique used in this study was Purposive Sampling. The study was conducted from April to May 2021 located at X Sub-district. The research revealed that the perception of the threat of fire disaster statistically had a significant relation ( $p$-value $=0.000)$ with the Evacuation Decision Making. It is expected to the local stakeholder to provide valid information regarding the risk of the fire disaster in the future, including informing them of the risk on individual safety, property, and function damage to the community through direct socialization so then the society can aware of how to organize the emergency response plans and can overcome the diversity of perceptions of local residents.
\end{abstract}

Keywords: $\quad$ Evacuation, Decision-Making, Fire-Disasters, Threat Perceptions

\begin{abstract}
ABSTRAK
Bencana kebakaran yang terjadi di Kelurahan X, merupakan salah satu bencana terbesar sepanjang tahun 2018-2020 di Kota Palembang dikarenakan Kelurahan tersebut merupakan kawasan pemukiman padat penduduk, sehingga memungkinkan untuk berkontribusi besar pada keberhasilan tanggap darurat bencana selanjutnya. Tindakan Evakuasi merupakan bagian dari Emergency Response Plan yang bertujuan untuk mengurangi dampak dari suatu bencana. Pengambilan keputusan tindakan evakuasi dipengaruhi oleh beberapa faktor yang mempengaruhinya salah satunya Persepsi individu terhadap Ancaman Bencana Kebakaran. Maka dari itu penelitian ini bertujuan untuk mengetahui hubungan Persepsi terhadap Ancaman Bencana Kebakaran terhadap pengambilan keputusan evakuasi bencana kebakaran. Jenis penelitian yang digunakan yaitu penelitian kuantitatif dengan desain Cross Sectional. Teknik pengambilan sampel menggunakan Purposive Sampling. Penelitian dilakukan pada bulan April hingga Mei tahun 2021 di Kelurahan X. Hasil penelitian didapatkan, Persepsi terhadap Ancaman Kebakaran secara statistik memiliki hubungan bermakna ( $p$-value $=0,000)$ dengan Pengambilan Keputusan Evakuasi. Diharapkan untuk Stakeholder setempat untuk kedepannya memberikan informasi tentang bahaya/ risiko bencana kebakaran dan kemungkinan efeknya pada keselamatan individu, kerusakan properti dan fungsi pada masyarakat melalui sosialisasi langsung sehingga masyarakat yang tinggal di daerah rawan bencana kebakaran dapat membuat rencana tanggap darurat dan menangani keragaman persepsi penduduk daerah pemukiman padat yang rawan bencana kebakaran.
\end{abstract}

Kata Kunci: Evakuasi, Kebakaran, Persepsi Ancaman, Pengambilan Keputusan 


\section{PENDAHULUAN}

Kejadian kebakaran di Indonesia terbilang cukup tinggi, khususnya di pemukiman masyarakat menengah kebawah memiliki kepadatan yang cukup tinggi. Dalam kurun waktu sepuluh tahun terakhir, tercatat sebanyak 1212 kejadian kebakaran yang ada di Indonesia dengan angka kematian sebesar 97, angka penderitaan sebesar 84834, dan korban luka-luka sebanyak 486 (Badan Nasional Penanggulangan Bencana, 2020).

Bencana kebakaran di Kecamatan X tepatnya di Kelurahan X, Kota Palembang merupakan salah satu kasus bencana kebakaran di pemukiman penduduk yang paling sering terjadi sebanyak 16 kali dan kejadian kebakaran terbesar dalam kurun waktu 2018-2020 telah terjadi di RT 06 dan 08 Kelurahan X, Kota Palembang sedikitnya tercatat sebanyak 84 kepala keluarga telah kehilangan tempat tinggal (Badan Penanggulangan Bencana Daerah Prov. Sumatera Selatan, 2021) dengan rincian 62 Rumah yang hangus terbakar dan korban yang dievakuasi sebanyak 316 orang serta unit pemadam kebakaran yang berhasil dikerahkan melebihi 10 unit Fire Truck dan melibatkan 1 Fireboat dan 2 Pool (Dinas Pemadam Kebakaran dan Penanggulangan Bencana Kota Palembang, 2021).

Tindakan Evakuasi merupakan salah satu bagian dari Emergency Response Plan yang dilakukan untuk mengurangi dampak fisik, sosial, maupun psikologis pada tatanan masyarakat dari suatu bencana (Supartini et al., 2017). Sehingga para ahli manajemen kebakaran diberbagai negara merekomendasikan tindakan evakuasi sebagai tindakan yang dapat diambil masyarakat saat terancam oleh bencana kebakaran (Edgeley dan Paveglio, 2019).

Sebagian besar studi terdahulu yang menganalisis proses pengambilan keputusan tindakan evakuasi bencana menggunakan teori Protective Action Decision Model $(P A D M)$ didalamnya terdapat beberapa faktor yang mempengaruhinya termasuk proses persepsi individu terhadap ancaman bencana (Lindell dan Perry, 2012). Pada dasarnya, jika individu berpikir bahwa mereka merasakan ancaman dan risiko dari bahaya bencana maka mereka lebih mungkin untuk mengambil tindakan evakuasi atau membuat penyesuaian mitigasi bahaya bencana (McCaffrey, Wilson dan Konar, 2018). Namun, proses pengambilan keputusan evakuasi merupakan hal yang cukup rumit dilakukan bagi sebagian individu sehingga dapat menunda proses evakuasi.

Berdasarkan data demografi di lapangan, survey awal dan wawancara awal, karakteristik Kelurahan $\mathrm{X}$ merupakan kawasan pemukiman penduduk pinggir perkotaan yang cukup padat. Bencana kebakaran di Kelurahan X, Kecamatan X Kota Palembang yang terjadi pada bulan Oktober 2019 merupakan peristiwa bencana yang menarik perhatian, skalanya relatif cukup besar dan secara langsung mengancam nyawa saat bencana kebakaran tersebut terjadi. Hal tersebut berkontribusi pada keberhasilan tanggap darurat bencana selanjutnya.

Penelitian ini diharapkan dapat menganalisis sebab-akibat masyarakat dalam mengambil keputusan evakuasi masyarakat beserta seluruh anggota keluarganya agar dapat menerapkan prosedur keselamatan (Safe-Action), membuat rencana kesiapsiagaan dan lebih siap menghadapi situasi darurat bencana kebakaran. Berdasarkan permasalahan tersebut tujuan penelitian ini adalah untuk menganalisis hubungan antara faktor persepsi Kepala Keluarga terhadap Ancaman Bencana Kebakaran yang terjadi di Kelurahan X Kota Palembang.

\section{METODE}

Jenis penelitian yang digunakan dalam penelitian ini adalah kuantitatif dengan desain Cross Sectional. Penelitian dilakukan di Kelurahan X, Kecamatan X, Kota Palembang. Waktu penelitian ini dilakukan pada bulan April-Mei tahun 2021. Populasi penelitian ini adalah masyarakat yang 
tinggal di Kelurahan X. Teknik penentuan sampel penelitian menggunakan Hypothesis Test for Two Population Proportions (two sided test) dengan teknik pengambilan sampel Purposive Sampling dan didapatkan 6 Rukun Tetangga sebagai pilihan sampel, kemudian ditentukan jumlah yang mewakilkan sampel penelitian di seriap Rukun tetangga dengan teknik Probability Proportion to Size Sampling dengan kriteria inklusi a) Berumur 18 tahun ke atas b) merupakan kepala keluarga atau mewakili.

Jumlah responden penelitian 161 kepala keluarga. Teknik pengumpulan data yang digunakan dengan menggunakan kuesioner yang dimodifikasi dan telah diuji validitas dan reliabilitasnya. Analisis data dengan menggunakan analisis univariat dan bivariate dengan menggunakan uji ChiSquare. Penelitian ini dilaksanakan setelah mendapat izin dari komisi etik di Fakultas Kesehatan Masyarakat Univerisitas Sriwijaya dengan No : 078/UN.9/FKM.TU.KKE/2021

\section{HASIL}

Karakteristik Responden Tabel 1. Karakteristik Responden

\begin{tabular}{|c|c|c|}
\hline Umur & $\mathbf{n}$ & $\%$ \\
\hline$\geq 65$ Tahun & 23 & 14,3 \\
\hline$<65$ Tahun & 138 & 85,7 \\
\hline Jenis Kelamin & $\mathbf{n}$ & $\%$ \\
\hline Perempuan & 73 & 45.3 \\
\hline Laki-laki & 88 & 54.7 \\
\hline Pendidikan & $\mathbf{n}$ & $\%$ \\
\hline Tinggi $\geq$ SMA & 90 & 55.9 \\
\hline Rendah $<$ SMA & 71 & 44.1 \\
\hline Lama Tinggal & $\mathbf{n}$ & $\%$ \\
\hline$\geq 10$ Tahun & 118 & 73.3 \\
\hline$<10$ Tahun & 43 & 26.7 \\
\hline Komposisi Anggota Keluarga & $\mathbf{n}$ & $\%$ \\
\hline$\geq 4$ Orang & 120 & 74.5 \\
\hline$<4$ Orang & 41 & 25.5 \\
\hline $\begin{array}{c}\text { Persepsi Terhadap Ancaman } \\
\text { Bencana Kebakaran }\end{array}$ & $\mathbf{n}$ & $\%$ \\
\hline Sangat Mengancam & 95 & 51 \\
\hline Kurang Mengancam & 66 & 49 \\
\hline
\end{tabular}

Berdasarkan Tabel 1. menunjukkan bahwa sebagian besar Kepala Keluarga (KK) di Kelurahan X berumur < 65 tahun sebesar $138 \mathrm{KK}(85,7 \%)$, berjenis kelamin laki-laki dengan jumlah 88 KK (54.7\%), tingkat pendidikan yang cukup tinggi $(\geq$ SMA) dengan jumlah 90 KK (55.9\%), Status Rumah adalah Milik Sendiri dengan jumlah $122 \mathrm{KK}(75.8 \%)$, lama tinggal $\geq 10$ Tahun dengan jumlah 118 KK (73.3\%), komposisi anggota keluarga dengan berjumlah lebih dari empat orang sebanyak 120 KK (74.5\%) dan Jumlah Kepala Keluarga yang menyatakan bahwa bencana kebakaran yang telah terjadi merupakan bencana yang sangat mengancam berjumlah $95 \mathrm{KK}(51 \%)$.

Tabel 2. Distribusi Responden Berdasarkan Pengambilan Keputusan Evakuasi Bencana Kebakaran

\begin{tabular}{lcc}
\hline $\begin{array}{c}\text { Pengambilan Keputusan } \\
\text { Evakuasi Bencana Kebakaran }\end{array}$ & n & \% \\
\hline Melakukan Evakuasi Dini & 84 & 52.2 \\
Tetap Bertahan Di Rumah & 77 & 47.8 \\
\hline
\end{tabular}

Berdasarkan Tabel 2. menunjukkan bahwa jumlah kepala keluarga yang menyatakan bahwa mereka melakukan evakuasi dini saat bencana kebakaran terjadi sebanyak 84 KK (52.2\%), mereka yang tetap bertahan di Rumah dan menyelamatkan properti dan barang berharga mereka saat kejadian bencana kebakaran sebanyak 77 KK (47.8\%).

\begin{tabular}{|c|c|c|c|c|c|c|}
\hline Tabel & $\begin{array}{l}3 . \\
\text { terh } \\
\text { Keb } \\
\text { Kep }\end{array}$ & $\begin{array}{l}\text { an } \\
\text { an } 1\end{array}$ & $\begin{array}{l}\text { A } \\
\text { Anc } \\
\text { Deng } \\
\text { vakua }\end{array}$ & I & $\begin{array}{r}\mathrm{Pe} \\
\mathbf{B e} \\
\text { ngan }\end{array}$ & $\begin{array}{l}\text { sepsi } \\
\text { icana } \\
\text { bilan }\end{array}$ \\
\hline \multirow{3}{*}{\multicolumn{2}{|c|}{$\begin{array}{l}\text { Persepsi } \\
\text { Ancaman }\end{array}$}} & \multicolumn{4}{|c|}{$\begin{array}{c}\text { Pengambilan } \\
\text { Keputusan Evakuasi }\end{array}$} & \\
\hline & & \multicolumn{2}{|c|}{$\begin{array}{l}\text { Evakuasi } \\
\text { Dini }\end{array}$} & \multicolumn{2}{|c|}{$\begin{array}{c}\text { Tetap } \\
\text { Bertahan }\end{array}$} & $\begin{array}{c}\text { Valu } \\
e\end{array}$ \\
\hline & & $\mathbf{N}$ & $\%$ & $\mathbf{N}$ & $\%$ & \\
\hline \multirow{2}{*}{\multicolumn{2}{|c|}{$\begin{array}{l}\text { Sangat } \\
\text { Mengancam }\end{array}$}} & 70 & 73.7 & 25 & 26.3 & \multirow{3}{*}{0.000} \\
\hline & & & & & & \\
\hline Kurang & & 14 & 21.2 & 52 & $\begin{array}{ll}79.8 \\
\end{array}$ & \\
\hline
\end{tabular}


Hasil analisis menunjukkan nilai untuk variabel Persepsi terhadap Ancaman Bencana Kebakaran p-value $=0,000(\alpha \leq$ $0,05)$ sehingga terdapat hubungan secara statistik dengan pengambilan keputusan tindakan evakuasi. Jumlah kepala keluarga yang memiliki persepsi bahwa bencana kebakaran merupakan hal yang sangat mengancam bagi diri, keluarga, properti dan barang berharga dan melakukan evakuasi dini saat kebakaran terjadi berjumlah 70 KK, Sedangkan jumlah kepala keluarga yang memiliki persepsi bahwa bencana kebakaran merupakan hal yang kurang mengancam bagi diri, keluarga, properti dan barang berharga berjumlah $52 \mathrm{KK}$.

\section{PEMBAHASAN}

\section{Hubungan Persepsi terhadap Ancaman Bencana Kebakaran dengan Pengambilan Keputusan Evakuasi}

Hasil penelitian ini menunjukkan bahwa terdapat adanya hubungan antara Persepsi Ancaman terhadap Pengambilan Keputusan Evakuasi Bencana Kebakaran dengan $p$-value $=0,000(\alpha<0,05)$. Hasil ini sejalan dengan penelitian yang dilakukan oleh Heath et al., (2018) yang melakukan analisis faktor yang mempengaruhi pengambilan keputusan tindakan protektif terhadap suatu bencana di komunitas manufaktur petrokimia berisiko tinggi Deer Park, Texas, Amerika Serikat yang didapatkan bahwa variabel Persepsi Ancaman secara signifikan mempengaruhi masyarakat dalam pengambilan keputusan tindakan protektif bencana.

Berdasarkan hasil temuan di Lapangan, beberapa kepala keluarga menyatakan bahwa mereka merasa terancam saat bencana kebakaran terjadi, dan bencana kebakaran berdampak terhadap properti dan barang berharga mereka. Hal ini didasarkan pada saat melakukan wawancara singkat dengan Kepala Keluarga, bahwa jika properti dan barang berharga mereka terancam, keselamatan pribadi mereka juga akan terancam.
Hasil temuan ini juga diperkuat berdasarkan informasi yang didapatkan dari kepala keluarga keluaran X, kepala keluarga juga memiliki Persepsi terhadap Ancaman Bencana Kebakaran menjadi lebih besar dikarenakan kekhawatiran mereka terhadap jenis rumah mereka yang sebagian besar semi-permanen dan memiliki jarak kurang dari satu meter dari rumah tetangga sehingga tingkat kecemasan dan perasaan bahwa bencana kebakaran yang terjadi merupakan hal yang mengancam menjadi lebih besar.

Banyak penelitian mencatat bahwa semakin besar risiko atau ancaman suatu bencana yang dirasakan, semakin besar kemungkinan individu untuk melakukan evakuasi (Folk et al., 2019). Penelitian yang dilakukan oleh Huang, Lindell dan Prater, (2016) juga didapatkan bahwa variabel persepsi ancaman bencana badai Hurricane Katrina dan Rita terhadap diri, keluarga, dan rumah meningkatkan kemungkinan masyarakat untuk melakukan evakuasi bencana.

Persepsi ini menjadi dasar bagi kepala keluarga sebagai pengambil keputusan dalam satu rumah tangga dalam mengambil keputusan tindakan evakuasi dengan mempertimbangkan apakah ada ancaman nyata, kebutuhan untuk tindakan protektif, pilihan perlindungan yang tersedia, alternatif tindakan protektif dan waktu akan pelaksanaan evakuasi (Lindell, 2013).

Hasil penelitian yang dilakukan oleh Wallace, Poole dan Horney, (2016) yang meneliti hubungan antara persepsi ancaman bencana bencana badai Hurricane Irene terhadap tindakan evakuasi pada daerah rawan banjir di Carolina Utara, Amerika Serikat didapatkan bahwa rumah tangga yang merasa terdapat adanya ancaman dan risiko tinggi terhadap bencana banjir lebih memilih untuk melakukan evakuasi daripada penghuni rumah yang merasakan ancaman dan risiko rendah.

Dalam teori PADM (Protective Action Decisions Model) faktor isyarat lingkungan, isyarat sosial serta pesan peringatan bencana yang pada gilirannya menimbulkan 
persepsi dari ancaman bahaya dan risiko suatu bencana (Lindell and Perry, 2012). Teori Protective Action Decisions Model (PADM) yang dikemukakan juga menyatakan bahwa terdapat tiga faktor yang mempengaruhi individu dalam menentukan persepsi ancaman bencana, yaitu intrusi ancaman, pengalaman akan bahaya bencana kebakaran, dan kedekatan akan bahaya bencana.

Namun berdasarkan penelitian yang dilakukan oleh Stein et al., (2013) didapatkan hasil sebaliknya, yaitu responden penelitian yang memiliki pengetahuan akan bahaya bencana kebakaran memiliki persepsi bahwa bencana kebakaran yang terjadi hanya mengancam atau berisiko pada diri mereka sehingga mereka hanya akan berfokus pada tindakan penyelamatan jiwa saja.

Hal ini berkaitan dengan faktor isyarat sosial, Individu mungkin menafsirkan pesan peringatan bencana dan sumber informasi bencana dengan menggunakan cara pemahaman yang berbeda sehingga dapat menghasilkan persepsi ancaman dan risiko bencana yang berbeda (Strahan, Whittaker dan Handmer, 2019).

Berbeda halnya dengan penelitian yang dilakukan oleh Strahan dan Watson, (2019) yang didapatkan bahwa persepsi ancaman tidak menunjukkan hubungan signifikan terhadap pengambilan keputusan evakuasi bencana kebakaran hutan di Australia dengan nilai $p$-value $=0,170$ karena masyarakat hanya tidak merasa bahwa ancaman tersebut mengancam diri mereka tetapi hanya mengancam properti dan barang berharga mereka sehingga hal tersebut meyakinkan mereka untuk tetap bertahan di rumah mempertahankan properti dan barang berharga mereka.

Persepsi akan ancaman bahaya bencana adalah keterampilan untuk mendeteksi ancaman yang berkembang. Beberapa peneliti terdahulu berpendapat bahwa persepsi akan ancaman atau bahaya bencana mencerminkan kesadaran untuk situasi berbahaya di lingkungan (Horswill dan McKenna 2004). Persepsi ancaman atau risiko merupakan salah satu faktor penting yang berkaitan dengan pengambilan keputusan tindakan protektif. Persepsi ancaman atau risiko bencana dicirikan sebagai besarnya dampak konsekuensi terhadap diri pribadi dan keluarga dengan bentuk reaksi berupa ketakutan dan kecemasan. (Jaeger, et al., 2001)

\section{KESIMPULAN}

Faktor Persepsi Ancaman ( $p$-value = 0,000 ), memiliki hubungan yang bermakna terhadap pengambilan Keputusan Evakuasi Bencana Kebakaran di Kelurahan X, Kecamatan X Kota Palembang.

Disarankan untuk Peneliti selanjutnya dapat melakukan Penelitian lebih lanjut untuk memperkuat kerangka konseptual pengambilan keputusan evakuasi bencana melalui faktor lingkungan, sosial dan karakteristik demografi yang terbukti penting dalam perilaku individu terutama rumah tangga dalam menghadapi bencana kebakaran.

Disarankan juga bagi Pemangku Kepentingan setempat (RT, RW atau Lurah) untuk kedepannya dapat memberikan informasi tentang bahaya dan risiko akan bencana kebakaran dan kemungkinan efeknya pada keselamatan diri, properti dan fungsi pada masyarakat melalui sosialisasi langsung sehingga masyarakat yang tinggal di daerah rawan bencana kebakaran dapat membuat rencana tanggap darurat dan menangani keragaman persepsi penduduk daerah pemukiman padat penduduk yang rawan bencana kebakaran.

\section{UCAPAN TERIMA KASIH}

Dalam penelitian ini, peneliti mengucapkan terima kasih kepada dosen Program Studi Magister Ilmu Kesehatan Masyarakat Universitas Sriwijaya, Warga Kelurahan X, Kota Palembang serta seluruh jajaran Pemangku Kepentingan Kelurahan $\mathrm{X}$ baik Lurah dan Ketua RT dalam membantu proses penelitian ini. 


\section{DAFTAR PUSTAKA}

Badan Nasional Penanggulangan Bencana (2020) Bencana Non Alam di Indonesia Tahun 2010 s/d 2020. Jakarta.

Badan Penanggulangan Bencana Daerah Prov. Sumatera Selatan (2021) Data Kejadian Bencana di Provinsi Sumatera Selatan Tahun 20182020. Palembang.

Dinas Pemadam Kebakaran dan Penanggulangan Bencana Kota Palembang (2021) Data Kejadian Kebakaran Tahun 2015-2020. Palembang.

Edgeley, C. M. \& and Paveglio, T. B. (2019) 'Exploring influences on intended evacuation behaviors during wildfire: What roles for prefire actions and event-based cues?', International Journal of Disaster Risk Reduction, 37(April), p. $101182 . \quad$ doi: 10.1016/j.ijdrr.2019.101182.

Folk, L. H. et al. (2019) 'A Provisional Conceptual Model of Human Behavior in Response to WildlandUrban Interface Fires', Fire Technology, 55(5), pp. 1619-1647. doi: 10.1007/s10694-019-00821-z.

Heath, R. L. et al. (2018) 'Risk Communication Emergency Response Preparedness: Contextual Assessment of the Protective Action Decision Model', Risk Analysis, 38(2), pp. 333-344. doi: 10.1111/risa.12845.

Huang, S. K., Lindell, M. K. and Prater, C. S. (2016) 'Who Leaves and Who Stays? A Review and Statistical Meta-Analysis of Hurricane Evacuation Studies', Environment and Behavior, 48(8), pp. 991-1029. doi: 10.1177/0013916515578485.

Jaeger, C.C., Renn, O., Rosa, E.A., \& Webler, T. (2001) 'Risk, Uncertainty, and Rational action', Earthscan.
Lindell, M. K. (2013) 'Disaster Studies', Current Sociology, 61(5-6), pp. 797-825. doi: 10.1177/0011392113484456.

Lindell, M. K. and Perry, R. W. (2012) 'The Protective Action Decision Model: Theoretical Modifications and Additional Evidence', Risk Analysis, 32(4), pp. 616-632. doi: $10.1111 / \mathrm{j} .1539-$ 6924.2011.01647.x.

McCaffrey, S., Wilson, R. and Konar, A. (2018) 'Should I Stay or Should I Go Now? Or Should I Wait and See? Influences on Wildfire Evacuation Decisions', Risk Analysis, 38(7), pp. 1390-1404. doi: 10.1111/risa.12944.

Stein, R. et al. (2013) 'How Risk Perceptions Influence Evacuations from Hurricanes and Compliance with Government Directives', Policy Studies Journal, 41(2), pp. 319-342. doi: 10.1111/psj.12019.

Strahan, K. W., Whittaker, J. and Handmer, J. (2019) 'Predicting self-evacuation in Australian bushfire', Environmental Hazards, 18(2), pp. 146-172. doi: 10.1080/17477891.2018.1512468.

Strahan, K. and Watson, S. J. (2019) 'The protective action decision model: when householders choose their protective response to wildfire', Journal of Risk Research, 22(12), pp. 1602-1623. doi: 10.1080/13669877.2018.1501597.

Supartini, E. et al. (2017) 'Membangun Kesadaran,Kewaspadaan, dan Kesiapsiagaan dalam Menghadapi Bencana', Buku Pedoman Latihan Kesiapsiagaan Bencana, 1(1), p. 145. 
Wallace, J. W., Poole, C. and Horney, J. A. (2016) 'The association between actual and perceived flood risk and evacuation from Hurricane Irene,
Beaufort County, North Carolina', Journal of Flood Risk Management, 9(2), pp. 125-135. doi: 10.1111/jfr3.12115. 